\title{
Distributed energy production in a polycentric scenario: policy reforms and community management
}

\author{
Stefano Moroni \& Luca Tricarico \\ Department of Architecture and Urban Studies, Politecnico di Milano
}

\begin{abstract}
Any discussion of distributed energy systems inevitably centres on how they compare with the large energy systems, i.e. the traditional centralised model of energy production, and on the viability of local energy systems as alternatives in terms of efficiency and sustainability. At present, the debate on local energy systems and distributed energy production hinges mainly on questions of technology and engineering; at most, some reflections on economy are thrown in. What we believe is essential is to cast the net wider and include other dimensions. In particular, we also need to consider in greater depth the organisational and institutional issues involved until now, less considered and discussed. In this perspective, the main question addressed by the present article is if and how new forms of local organisations can provide the crucial catalyst for a new polycentric distributed energy scenario
\end{abstract}


"The obstacles to powering the world with wind, water, and sunshine are primarily social and political, not technical or economic" (Delucchi and Jacobson, 2013).

"The regulatory support for microgrid developments have yet to coalesce" (Asmus, 2010).

"Ultimately, the most effective smart grid will be one in which intelligence is sourced from users as well as devices" (Goulden et al., 2014).

\section{Introduction: the many faces of distributed energy}

An energy system is an energy chain that comprises energy production, conversion, transmission, distribution and consumption (Alanne and Saari, 2006). The technologies currently available to create distributed energy systems have reached a promising level of advancement. ${ }^{1}$

Any discussion of distributed energy systems inevitably centres on how they compare with the large energy systems, i.e. the traditional centralised model of energy production, and on the viability of local energy systems as alternatives in terms of efficiency and sustainability. At present, the debate on local energy systems and distributed energy production hinges mainly on questions of technology and engineering; at most, some reflections on economy are thrown in for good measure. What we believe is essential is to widen our view and include other dimensions.

In particular, we also need to consider in greater depth the organisational and institutional issues involved - until now less considered and discussed, as underscored by Hoffman and High-Pippert (2005), Alanne and Saari (2006), Ribeiro et al. (2012), Sovacool (2014). In this regard, Friedrichsen et al. (2014:

1 More specifically, the relevant technologies in this case can be grouped into four main categories, as follows: first, production technologies related to the production of energy, i.e. those that enable the on-site production of the energy needed by the local system (particularly important here are those technologies based on different types of renewable sources: photovoltaic systems or solar thermal, small wind turbines, small-scale hydropower, geothermal, biomass); second, distribution technologies, i.e. the technologies for the proper flow within local systems (crucial here are so-called microgrids); third, storage technologies (usually considered deficient, they have recently achieved a promising level of efficiency: A recent report published by UBS (2014) shows a vast market potential of storage technologies in the next twenty years, which will see an up to $50 \%$ reduction in energy storage costs by the year 2020.); fourth, management technologies that enable the control of the assets of production, distribution, storage, and consumption of energy (i.e. the software systems that monitor energy consumption patterns and make it possible to optimise consumption and ensure the efficiency of the local energy grid, and the hardware system comprising computers, sensors, meters, switches) (see for instance Chicco and Mancarella, 2009; Toledo et al., 2010; Mendes et al., 2011; Rezaie and Rosen, 2012). 
264) observe for instance that "the institutional set-up of the [distributed] smart system is still uncertain". Johnson and Hall (2014: 149) likewise observe that: "The systemic institutional transformation necessary to support wide-spread adoption of community/decentralised energy schemes ... [has] received limited attention to date". The crucial issue here is that in a distributed energy system "distribution" refers not only to energy generation units, but also to ownership, decision-making and responsibility as regards energy supply (Alanne and Saari, 2006). In short, distributed energy involves much more than merely situating smaller energy units close to consumers. "Energy" is not simply an economic asset or an ecological phenomenon; it is also a social relation (Calvert, 2015).

In this perspective, the main question addressed by the present article is if and how new forms of local organisations can provide the crucial element of a new polycentric distributed energy system. The first Section is devoted to delineate the main features of this system (small power plants located closer to consumers, smart microgrids, multiple voluntary communities initiatives) and an enabling institutional framework (based on new market and planning rules, more room for contractual communities, simplified compliance fulfilments, particular incentives and tax cuts). The first part of this Section is mainly analytical and explanatory while the second is propositive and normative (openly based also on certain value assumptions). It is important to stress here that, although a certain degree of consensus seems to pervade the logic of renewable distributed energy systems, diverse rationales are in fact involved (Bulkeley et al., 2014); we believe that it is more productive to bring out and highlight these differences - and to base more distinctive and differentiated arguments on them - than to merely concentrate on similarities. The second Section considers the possible benefits of a polycentric system (both from a systemic and an individual point of view) and its spatial effects (such as "inverted territorialisation" and new roles for multiple socialspatial nodes). This section is mainly based on empirical evidence from the scientific literature on the subject. The concluding Section considers a "programmatic" idea of multiple utopias (evidencing how substantive utopias can only be local variegated experiments within a more general and abstract common institutional framework), and underscores new possible roles for planners in the delineated scenario. These three sections are interconnected, but because they regard different levels of discourse, they do not directly derive from each other; therefore, they can be criticised separately (for example: certain value assumptions - such as the importance of freedom, autonomy, and empowerment - are open to criticism from different normative points of view; new empirical data and figures can evidence supplementary advantages or problems of 
traditional or renovated energy production and distribution systems).

\section{Towards polycentric energy systems}

2.1. Three main features: small power plants closer to consumers, smart microgrids, multiple voluntary community initiatives

The world's major energy networks continue to provide the structure for the bulk of human activity, and are hence essential for the proper functioning of today's societies. They furnish linkage between producers and consumers, energy for offices and homes, and heating and air-conditioning according to the changing climatic conditions. According to a recent report considering 10 countries (United States, Canada, United Kingdom, Germany, Spain, China, Poland, Italy, India, South Africa), the value of a country's overall infrastructure stock (including energy, but also roads and so on) on average amounts to $70 \%$ of its GDP - that is, an enormous amount of capital (Dobbs et al., 2013). Given such a massive employment of physical and financial assets, at first sight any alteration to this set-up would seem impracticable.

Electricity today is principally generated by large power plants, which are usually located at a considerable distance from the end-users, who receive it via long and complex networks of power lines. The United States electric grid, for instance, comprises more than 482,000 kilometres of transmission lines (U.S. Department of Energy, 2013). Even in a smaller country as Italy, the current national power grid is composed of 72,000 kilometres of cables (www.terna.it).

A possible alternative scenario centred on distributed energy production would entail the creation of numerous smaller, modular plants located closer to the places where that energy is actually being consumed. At present, such a set-up could come about by combining traditional power plants burning fossil fuels with others using renewable sources. In the future, distributed energy production could rely entirely on the latter sources: photovoltaic panels, solar thermal, small wind turbines, small-scale hydropower and geothermal plants. Basically, this distributed energy scenario is the only arrangement that would enable a extensive network of renewable energy sources to function.

If we embrace this idea of distributed energy production, we need also to think about what kinds of organisations would be appointed to manage these new initiatives. The concept opens up an entirely new gamut of opportunities in collective energy production and management. The nodes of this new polycentric system of energy production will not be - solely and merely - individual homes, 
stores, or industries (as is often considered, also in terms of new legislative measures) $)^{2}$, but also new forms of "intentional/voluntary communities" (Brunetta and Moroni, 2011). ${ }^{3}$

These communities may be formed to deal solely with energy issues; or they can coincide with place-based contractual communities, such as homeowners associations, residential cooperatives, cohousing complexes, multi-tenant properties (Moroni, 2014). We believe that the latter situation is the more promising one - particularly if these place-based communities are conceived and designed as "integrated energy-management systems" able to deal simultaneously and in integrated manner with such services as electric power, lighting, heating, air conditioning, water supply, sewerage, waste management, communications, etc. (Lowi and MacCallum, 2014). Obviously, these contractual communities can make use of any form of external collaboration or cooperation with third parties (Houck and Rickerson, 2009; Tricarico, 2015).

Moreover, such units could easily form coalitions to create a wider framework of sorts; that is, private associations of private communities. Their desirability and feasibility would be decided from time to time on a bottom-up basis.

In short, here we are concerned in particular with cases in which the production and distribution of energy are closely connected with forms of (private) selfgovernance (Cayford and Scholten, 2014). To be stressed is that private community energy enterprises can be for-profit or non-profit (or both). There is no reason inherent to the idea of a community energy enterprise that requires it to be a "third party", "non-profit" body (as some instead seem to believe). The distinction between for-profit and non-profit is not as important as has been maintained: in both cases, what matters is these are voluntary actions within civil society (Beito et al., 2002). The idea itself of entrepreneurship is not necessarily tied to the profit of single individuals; it can regard any type of activity, including group activity (Cato et al., 2008).

Many misunderstandings have been caused also by a certain use of the term "community". Often used by studies on local energy services, "community" creates confusion because in many cases it is used, not as a descriptive concept, but as a value-laden one identifying something that is good in itself (Tame, 1998). That is to say, the expression is generally used to imply something indisputably

2 The current regulatory framework in most EU countries is often focused on creating incentives for individual technological solutions, such as, in Italy, "Titoli di Efficienza Energetica" (Energy Efficiency Tokens) or "Conto Energia” (Energy Account), by-passing the idea of collective solutions (Energy and Strategy Group, 2014).

3 See also the idea of "integrated community energy services" in Mendes et al. (2011) and the idea of "community energy systems" in Cayford and Scholten (2014). 
positive, including friendship, altruism, support, etc. One non-ideological mode of application (which we employ here) is to define a community in terms of two main components: certain interests shared by a number of individuals; and an integrative system of organisation that regulates the activities required for the community's operation. (Close personal ties are neither necessary nor excluded by the definition: MacCallum, 1970). In this sense, contractually organised communities are "communities of choice" or "intentional communities", not "communities of chance" or "community of fate"; they are "rule-bound communities" (Moroni, 2014).

The efficiency of a distributed system of electricity generation of this type would be guaranteed by the introduction of smart grids whereby the local units are rendered interactive via smart software protocols. This contrasts with the standard type of power grid with its single source and passive distribution, and instead would involve users interactively with the grid (they would be both consumers and producers, i.e. prosumers) connected to a network fed by multiple energy sources. As such, the smart network would be able to respond promptly to surges and dips in demand from the various end-users, thereby ensuring the optimal and immediate management of energy supply and demand (U.S. Department of Energy, 2014). Whilst in the traditional centralised energy system, demand and supply occupied separate spheres, here they are in direct connection (Goulden et al., 2014).

To this end, the production of on-site energy would not only benefit domestic appliances, commercial needs and so forth (heating, lighting, etc.), but it could also be used to recharge electric vehicles and the like. The interaction between electric vehicles and distributed energy systems based on smart microgrids presents some challenges, but also considerable opportunities. ${ }^{4}$

Clearly, the smart grid does not need to be a public utility; nor need it be unique or centralised. We can imagine a situation with myriads of microgrids working in parallel with wider grids or running in isolation (i.e. in a totally separated way: "islanded"). Such a scenario does away not only with the alleged intrinsic reasons for a "natural" monopoly of energy production, but also with the idea of "natural" distribution monopolies.

As Lowi and Crews write (2003: 164): "Historically ..., electric utilities never achieved natural monopoly status before the advent of the state public utility commissions that arose to regulate them". Compare with Geddes' (1992: 76)

4 On this issue (and on the technical problems and opportunities) see Waraich et al. (2010), Delucchi and Jacobson (2011), Zakariazadeh et al. (2014). 
observation: in the sector of electric utilities, "state regulation was instituted not to correct private market failures and to increase social welfare, but to provide firms with a way to insulate themselves from the discipline of competition". The issue is also emphasised by Foldvary (2005: 28): "Electricity provision has been regarded as a natural monopoly, a utility with a high fixed cost and low marginal cost. ... Historical studies have shown that governments have helped to create a monopoly situation - there may not be a natural monopoly".

Microgrids have a long history. Manhattan's Pearl Street Station power plant, the first to be constructed by Thomas Edison in 1882, was essentially a microgrid; by 1886, Edison's firm had constructed many other microgrids (Dunn, 2002; Warren, 2014). ${ }^{5}$ Shortly thereafter, the development of the electric services industry shifted towards a public-regulated centralised monopoly market, thus removing any incentive for a different microgrid evolution (Asmus, 2010). In this perspective, few economies of scale have been overestimated while larger diseconomies of scale have been overlooked (Bronin, 2010).

The same seems to apply to other services that have been centralised more for reasons of control and power than technical ones (consider postal services or, even, money: Hayek, 1976).

To conclude: We assume here that a polycentric approach is a productive way both to conceptualise distributed energy and to imagine a new institutional environment more favourable to distributed energy itself (Goldthau, 2014). A polycentric energy system is something more than merely a distributed energy system: polycentrism means not simply that energy production units are decentralised (and not centralised), but that they are under numerous, different and autonomous, forms of self-governance. The transition from a passive energy society to an active self-organising one is therefore a crucial element of a polycentric system of this kind.

5 "Thomas Edison had in mind when first installing his electric power-and-lighting systems in the late 19th-century. ... a dynamic, decentralized electricity industry, with dozens of companies generating and delivering power close to where it was to be used or even putting systems on site in customers' basements. And at first, electric power systems did indeed evolve along these lines, with hundreds of small "central-station" and isolated plants appearing in cities across the Western world. Small-scale power units were particularly popular in factories, which could save money by capturing and reusing their waste heat" (Dunn, 2002: 72). 
2.2. Four enabling measures: new market and planning rules, more room for contractual communities, simplified compliance fulfilments, particular incentives and tax cuts

Here we shall focus on how to foster the development of a polycentric energy system. It should be borne in mind that a large proportion of the energy demand by end-users is very small; three quarters of commercial and residential consumers in the United States, for instance, use electricity at an exceptionally low average rate: their average rate does not exceed 12 and 1.5 kilowatts respectively (Bronin, 2010).

Infrastructure is only one part of a far-reaching system composed as follows: the economic sectors, such as petrochemicals and transport; specific industries that produce energy plants and power devices; social environments; institutional, regulatory, and fiscal frameworks. Technologies co-evolve with the institutions and the social environment (Geels, 2002; Geels and Kemp, 2007). The current institutional and regulatory system has most certainly acted in favour of the large centralised energy production systems by establishing a framework of rules that have fostered the emergence of giant energy providers (Kiesling, 2010).

The traditional model of centralised energy production and distribution is so deeply embedded in the system of norms governing industry ad society that attempts to introduce changes of any kind are usually strongly resisted (Geels, 2014; Goldthau, 2014; Betsill and Stevis, 2016). This depends on concentrated interests, but also on biases and inertia. In the course of time, this entrenched model has spawned mammoth sector monopolies and consolidated the mechanisms that preserve the status quo. Here and there, efforts to promote distributed energy production have threatened the profit margins of the incumbent giants, unleashing waves of lobbying activity with the regulating bodies. ${ }^{6}$

According to Friedrichsen et al. (2014: 266), "present regulation often does not allow nor gives the right incentives to the network operator to interact with generation, storage, flexible loads and aggregators in order to harvest the efficiency benefit they can provide". The same point is made by Bronin (2010: 566): "By far the biggest barrier to the creation of microgrids is contradictory,

\footnotetext{
${ }^{6}$ As Geels (2014) notes, current, dominant "regime actors" in the electricity field try to defend the status quo through many forms of "resistance strategies"; among them: discursive strategies (i.e. setting agendas and framing public debate by exploiting their positions and media access); material strategies (i.e. directly using their resources and technical capabilities); broader institutional power (i.e. lobbying and influencing policy decisions).
} 
unclear, or hostile law". See also Johnson and Hall (2014): "Any serious effort to develop a decentralised energy system will inevitably require a different set of institutional arrangements to that which supports centralised energy production".

In order to foster local energy enterprises, and to unlock the power of distributed energy, the policy framework could include four types of measures which:

a) introduce new enabling rules;

b) grant more room for contractual communities;

c) simplify compliance fulfilments;

d) foster incentives and tax cuts.

The first intervention involves two main phases. First, eliminate the forms of protectionism that still today often protect traditional ways (centralised) to produce energy. Many energy markets have regulations that only allow large generators to operate and compete. In order for many distributed resources to enter these markets, these regulations will have to be changed to allow these smaller generators to compete (Newcomb et al., 2013: 80). It is necessary to remove all barriers to entry that prevent new forms of energy production from being competitive. In short: we must create a level playing field for open competition among all kinds of energy production systems, regardless of their type, size, technology, location, business model and ownership (Newcomb et al., 2013: 74). In particular: "Simplifying and reducing barriers to wholesale market participation for microgrids, both big and small, ... increases competition in the markets, [and] improves the economic case for microgrids" (ibid.: 83). ${ }^{7}$ In short: We have to grant non-discriminatory access to all kinds of businesses and initiatives. Some first steps towards greater liberalisation of the energy sector were taken in some developed countries during the 1980s and 1990s (Boyd, 2014). However, in many cases this liberalisation seems to be still partial, and it should become more profound and more radical. For example, many Italian organiaations and communities trying to develop local energy systems must constantly fight against regulatory, bureaucratic and fiscal barriers. ${ }^{8}$ With regard

7 Compare with Crousillat et al. (2010: 41): "Complying with a regulatory rule costs time and money. The costs are particularly important for off-grid operators because most off-grid enterprises operate at the edge of commercial viability. ... Unnecessarily cumbersome regulation can easily destroy the commercial viability of these enterprises. Therefore, in designing a light-handed regulatory system to support electrification, three questions need to be asked: (1) whether the information is really needed, (2) whether the number of review and approval steps can be reduced, and (3) whether the regulator can delegate some regulatory tasks to other entities".

8 See for instance the Melpignano Comunità Cooperativa (Puglia region), the EWerk Prad cooperative (Prato allo Stelvio, Trentino Alto Adige region), the Cooperativa Elettrica Gignod (Val D'Aosta region), the Società elettrica cooperativa 
to liberalisation, Bridge et al. (2013) write, referring to Great Britain: Although the reform of energy markets in the 1990s "might seem to have been a step in that direction through breaking the dominant role of the state, in practice the system that has developed is different largely in the balance of public and private power, but is still highly centralised". Second, it is necessary to avoid land-use planning and building standards that prevent the easy installation of local energy production systems. Effectively, "local land use laws thwart private builders' growing interest in building green" (Bronin, 2008: 248). In fact, certain building standards and planning regulations still constrain forms and uses of spaces and buildings too rigidly. Moreover, they do so in a manner that differs excessively from one city to another. Salkin (2012) recommends more uniform and less invasive local land-use and building regulations as the keys to unlocking the power of small scale renewable energy. For instance, height limitations, setback requirements, rights-of-way, etc. should be designed in a way that does not adversely affect the functionality of renewable energy systems. Moreover, building codes must place more emphasis on "performance standards" rather than "physical specifications". And there should be more uniform regulations relative to the built environment, and far fewer differences from site to site.

The second intervention involves three main steps. First, the most varied forms of place-based and other kinds of "contractual community" should be allowed: not only cooperatives but also diverse kinds of self-organised communities, such as homeowners associations, co-housing complexes, multi-tenant income properties, and so on. Second, any form of community energy enterprise should be allowed to sell any surplus energy that it produces. Third, the possibility of intentional islanding should be recognised: individuals and groups ought to have the right to operate/use their power systems in an island mode.

As regards the third intervention, let us consider for instance photovoltaic systems. In general, the cost of photovoltaic modules dropped by about $80 \%$ between 2007 and 2012, and prices are continuing to fall (Newcomb et al., 2013). The remaining costs - once the module has been paid for - today represent about $80 \%$ of the total photovoltaic system costs. So called "soft costs" - installation, interconnection, and permission and inspection procedures - can be significantly lowered by simplifying and streamlining public procedures (ibid.: 83). This is made clear, for instance, by the fact that soft costs were, in $2013,73 \%$ lower in 
Germany than in the U.S. (ibid.). ${ }^{9}$

As regards the fourth intervention, it is important that incentives and tax rebates are introduced without abnormally distorting market signals. A good way to do this is to avoid "asymmetrical", "non neutral" incentives. Incentives should become "neutral": that is, not providing incentives or disincentives only for very specific activities or commodities. Special asymmetric taxes and incentives prevent the rational allocation of resources and capital to the most productive and efficient endeavours (Allison, 2013: 197). Examples of non-neutral - asymmetric - tax codes that have failed in their aims include homeownership deduction, farm subsidies, and ethanol subsidies (ibid.). In our case, this means that incentives should not be introduced for specific technologies (for example, only photovoltaic systems, as has happened in Italy), but rather incentives or tax cuts for broader categories: for example, for all technologies (whatever they may be) that do not generate negative externalities X; for all technologies (whatever they may be) that relieve the public authorities of expenditure (for example, the extension of lines, connections, etc.); etc.

Obviously, here it has been possible to make only some general considerations. Entering more specifically into detail would require discussing the different administrative and regulatory barriers present in various countries, and making more contextualised proposals for reform. Interesting attempts in this direction have been made, for example, with reference to the United States, by Bronin (2010), Farrell (2011, 2012 and 2014), Salkin (2012), and, with reference to Great Britain, by Barton et al. (2015). ${ }^{10}$

9 Permitting processes (with reference for instance to photovoltaic systems) can be streamlined with the following steps: "Over-the-counter, same-day permit review. Clear, well-organized webpages focused on the ... permitting process, including recent changes in codes... Exempting building permit review altogether for small systems" (Newcomb et al., 2013: 84). Inspection processes can be streamlined with the following steps: "Self inspection (of certain types of systems) by certified ... installers. Simplifying requirements for site plans. Specifying how much of a project must be complete for interim inspections. Providing a tight time window for inspection appointments. Providing consistent and current training for inspectors so that installers receive actionable and reliable guidance. ... Combining all required inspections into one onsite visit" (ibid). On this issue, see also Pitt (2008).

10 On this issue see also Wiseman et al. (2011), Outka (2012), Warren (2014). 


\section{Possible benefits and spatial effects of polycentric energy systems}

\subsection{Ten possible benefits}

A polycentric system composed of multiple local energy systems has at least ten different positive effects. Note that some of the items considered below can be quantified, while for others this is not possible (this applies in particular to the eighth item, which has primarily a qualitative value; i.e. has a kind of meta-value).

First, polycentric distributed energy reduces power transmission and distribution losses. The U.S. Energy Information Administration estimates that national electricity transmission and distribution losses average about $6 \%$ of the electricity that is transmitted and distributed in the United States each year (average of losses from 1990 to 2012: www.eia.gov). Compare electric power transmission and distribution losses (\% of output) in other countries (2011): Denmark (7\%), Italy (7\%) Sweden (7\%), United Kingdom (8\%), Portugal (8\%), Spain (9\%), Turkey (14\%), Argentina (14\%), Brazil (16\%) (http://data.worldbank.org).

Second, polycentric distributed energy permits the recovery of residual heat. In the process of converting fuel in electricity, power generation systems usually produce heat as a side-effect: about two-thirds of the energy content of the input fuel is usually converted to heat; this heat is often wasted in many traditional central large generating plants (Akorede et al., 2010: 733). A network of scattered local systems could better harness and recycle residual heat for other energy uses, as opposed to the prohibitive costs of channelling the residual heat dispersed by large power stations over distances. In other words, small on-site devices like cogeneration units can better avoid the wastage of heat, leading to total efficiencies of $90 \%$ (consider that the overall efficiency of a coal-fired power plant is $30 \%$ to 60\%: Dunn, 2002).

Third, polycentric distributed energy is per se prevalently based on local resources and therefore more prone to use renewable resources (Scheer, 2010). Observe that a changeover to renewable resources (even up to 100 percent) is by no means unrealistic, neither technically nor economically. ${ }^{11}$ Note also that, for some technologies, such as photovoltaic panels, considerable improvements in

11 See Delucchi and Jacobson (2011 and 2013). As they write: "The private costs of generating onshore wind power, geothermal power, and hydropower already are less than the private costs of conventional fossil-fuel power ... . The cost of photovoltaic power is dropping rapidly, and if the photovoltaic industry continues to grow and improve technologically, by 2020 the cost will be comparable to the cost of conventional power, as will the cost of solar thermal power" (Delucchi and Jacobson, 2013: 34). 
terms of energy efficiency are going to be achieved: thanks to new materials, the current rate of conversion of sunlight into electricity, around $15 \%$, could rise to $40 \%$ or even $60 \%$ (Menna and Pauli, 2010; Muller, 2012). ${ }^{12}$ Consider, moreover, that distributed energy is more focused not only on local fuels but also on local human capital and contextual knowledge. Local energy systems can therefore combine two different modes of innovation: the STI (Science, Technology and Innovation) mode based on codified scientific and technical knowledge; and the DUI (Doing, Using and Interacting) mode focused on experience-based knowhow and informal processes of learning (Jensen et al., 2007).

Fourth, polycentric distributed energy reduces pollution (for instance, greenhouse gas emissions and other kinds of pollutants) and electromagnetic radiation. It is common knowledge that traditional power plants employing fossil fuels - in particular coal, natural gas, and oil - cause the emission of billions of tons of $\mathrm{CO}_{2}$ into the Earth's atmosphere every year: in 2012 the amount reached 34.5 billion tons (Oliver et al. 2013). In 2013, the average daily level of $\mathrm{CO}_{2}$ in the atmosphere exceeded 400 parts per million (Delucchi and Jacobson, 2013). The proportions of the world's electricity generation by fuel are the following: coal, 40.4\%; natural gas, $22.5 \%$; nuclear, $10.9 \%$; hydro, $16.2 \%$; oil, $5.0 \%$; other (geothermal, solar, wind, etc.), 5.0\% (IEA, 2014). The adoption of distributed generation technologies can play a crucial role in creating a cleaner form of energy with substantial environmental benefits. If they rely on cogeneration and renewable fuels, micro-power distributed technologies "have 50\% to $100 \%$ fewer emissions, on a per kilowatt basis, of particulates, nitrogen and sulphur oxides, mercury, and carbon dioxide" (Dunn, 2002: 78). It is also important to consider the other negative side-effects of large power transmission systems, such as electromagnetic pollution and the consequent risk to health. The magnetic field directly beneath a high voltage transmission line "is in the range of 300 and 600 $\mathrm{mG}$, and has a field strength of between 10 and $100 \mathrm{mG}$ at some $61 \mathrm{~m}$ away" (Akorede et al., 2010: 732). An empirical investigation (in England and Wales, conducted on 29,000 cases of childhood cancer, including 9,700 cases of leukaemia) noted a statistically significant increase in childhood leukaemia for populations living within 200 metres of an overhead transmission line, and a lesser (but still significant) increase in childhood leukaemia for populations living between 200 and 600 metres (Draper et al., 2005). As well known, the debate on these findings is still ongoing, ${ }^{13}$ but a precautionary principle suggests taking the

\footnotetext{
${ }^{12}$ For a review on recent trends in photovoltaic technology see Gul et al. (2016).

13 On this issue see also Olsen et al. (1993), Li et al. (1998), Sohrabi et al. (2010), Sermage-Faure et al. (2013).
} 
possibility seriously. Incidentally, empirical studies on property values show a decline in the market values of properties that are adjacent to high voltage overhead electric transmission lines (Delaney and Timmons, 1992; Sims and Dent, 2005). Clearly, health risks of this kind and the impact on property values of high voltage transmission lines would be substantially reduced with the introduction of a polycentric network based on distributed energy

Fifth, polycentric distributed energy reduces direct landscape impacts. Distributed small plants fit far more readily into the territory and landscape, with far less physical and visual impact on the environment. In other words, distributed energy eliminates extracting and mining sites, large power plants, and long transmission lines that severely and directly spoil the landscape. Distributed energy systems based on microgrids can therefore also help in reducing so-called "energy sprawl" (i.e., the phenomenon of the ever-increasing consumption of land to construct energy facilities) (Dunn, 2002; Akorede et al., 2010; Bronin, 2010; Warren, 2014). This will happen if the focus is not so much on renewable sources in themselves as on the use of distributed renewable energy systems based on microgrids. In this case, it will be easier to accommodate systems within the built environment and the infill land. "Onsite energy generation minimises the footprint with rooftop solar panels, small-scale wind, and combined heat and power systems built into existing structures" (Outka, 2011: 302). According to the U.S. Department of Energy (2004), cities and residences in the United States cover 140 million acres; applying photovoltaic panels to 7\% of this area (on building roofs, on the sides of buildings, on parking lots, along highway walls, etc.), the country's electricity requirements could be satisfied. Some doubts might arise in regard to wind turbines. Note, however, that, in the case of distributed generation, the emphasis is mainly on small wind turbines: "Distributed wind energy development has distinctive characteristics that make it an attractive source of alternative energy. Unlike industrial-scale wind energy projects, small wind turbine installations do not require the construction of costly access roads and transmission lines across vast stretches of rural land and thus pose less of a threat to wildlife and conservation areas" (Rule, 2010: 1237). On small wind turbines see for instance Blanch (2002), Mertens et al. (2003), Glass and Levermore (2011), Rehman et al. (2016). ${ }^{14}$

\footnotetext{
${ }^{14}$ Note that even nuclear power system consumes more land than what is usually recognised if we consider the entire nuclear fuel cycle, ranging from mining (for instance, uranium), milling and tailing disposal, through enrichment plants, the power plants themselves, and on to the final waste repository sites. Moreover, note that a nuclear power plant land occupation usually comprises also the controlled exclusion zones, including all areas barred to other uses and users (Lovins, 2001). In short: "Many nuclear advocates argue that renewable electricity has far too big a land 'footprint' to be environmentally acceptable,
} 
Sixth, polycentric distributed energy reduces risks of blackouts. Power blackouts are usually a combination of several factors, in particular high power plant utilisation, high power demand and/or high grid utilisation, defects due to material ageing (Bruch et al., 2011). Ten of the most severe recent blackouts were in New Zealand, 1998 (affected population: 70,000), Brazil, 1999 (97,000,000), India, 2001 (226,000,000), United States and Canada, 2003 (50,000,000), Italy, 2003 (56,000,000), Indonesia, 2005 (100,000,000), Spain, 2004 (2,000,000), South West Europe, including parts of France and Germany, $2006(15,000,000)$, Brazil and Paraguay, 2009 (87,000,000), Brazil, 2011 (53,000,000) (Bruch et al., 2011). Estimated for the well-known 2003 blackout in the United States and Canada - power was not restored for four days in some areas - was a total cost of $\$ 4$ to 8 billion (considering costs associated with spoiled or lost commodities, lost income for workers, costs to the affected utilities, extra costs to government bodies). In the United States even the many short blackouts which occur during a year - with an average of nine hours of disruptions each year for every consumer - sum to an annual economic loss of between \$ 104 and 164 billion (Bruch et al., 2011). The presence of multiple local energy systems will greatly reduce the risk of network power outages typical of the current unified grid systems, and which affect all users alike. In the case of polycentric distributed energy production units, the vulnerability of the entire system decreases because of independence from the global electricity distribution grid. Note that when blackouts occur in the current centralised systems, the blame is often placed on consumers, not on the system. This happens, for example, with the use of air conditioners during warm periods of the year: the problem of network overload is attributed to the (bad) habits of consumers, rather than to the inadequacy of the traditional centralised systems. (The same thing happens with the current, mainly centralised, systems of water supply: when water runs short, it is the fault of consumers who make "improper" use of it to wash their cars, for example, or to water the plants on their terraces).

Seventh, polycentric distributed energy systems would be far less vulnerable to possible acts of sabotage and terrorism - physical attacks or also cyber attacks. Today, centralised power system are classified as critical infrastructure in this regard, with consequent heavy expenses on national network security and defence organisation (Lewis, 2014). In the case of distributed generation, the vulnerability of the entire system greatly decreases. This is true even in cases of natural 
disasters.

Eight, polycentric distributed energy increases individual freedom. In other words, it increases self-sufficiency for consumers, expands their choices, reduces their dependency on the centre, and favours empowerment. Sometimes this is referred to as "more democracy", but the appropriate word - not usually liked in the current debate - is without doubt "freedom" or "liberty". Note this may also positively affect consumer awareness, and hence consumption behaviour patterns (Alanne and Saari, 2006; Houck and Rickerson, 2009). As well known to classical liberals, freedom goes hand in hand with responsibility (Hayek, 1960).

Ninth, polycentric distributed energy favours a greater range of solutions tailored to the needs of individuals and small groups. In this case, catch-all solutions are avoided - and should be avoided - by definition. ${ }^{15}$ Technological solutions will be, in this case, more place-based and consumer-based. In other words, distributed generation avoids the typical centralised approach of putting "all the eggs in the same basket" (Alanne and Saari, 2006).

Tenth, polycentric distributed energy fosters experimentation, innovation and competition (Kiesling, 2010 and 2012). "Shorter renewable energy supply chains ... make it impossible to dominate entire economies" (Scheer, 2002: 89). Distributed generation systems would promote the creation of non-hierarchical and competitive networks more flexible in responding to changing market situations and customer needs. Community energy projects have been recognised as potential "grassroots innovation niches" (Seyfang et al., 2014).

\subsection{Principal spatial effects}

Built environments are organised according to energy resources and energy power systems (Anderson et al., 1996; Alberti, 1999 and 2005). The form of the built environment is therefore influenced also by the nature of its fuel supply (Droege, 2002). ${ }^{16}$ The transition from centralised systems based on fossil fuel to more decentralised ones based on renewable resources will therefore also have important effect on spatial configurations.

Whilst geographers produced interesting analyses on the technological 
transition in progress (see for instance: Lawhon and Murphy, 2011; Knight, 2012; Raven et al., 2012; Bridge et al., 2013; Calvert, 2015 and 2016), urban studies have only recently paid attention to the issue (see in particular: Hodson and Marvin, 2010; Bolton and Foxon, 2013; Rutherford and Coutard, 2014; Bulkeley et al., 2014 and 2016; Dodson, 2014; Rydin et al., 2013; Coles et al., 2015; McLean, 2015; Affolderbach and Schulz, 2016); as Rutherford and Coutard (2014: 1354) write: "The important notion that energy transition processes (and changes to energy systems more generally) constitute (or might constitute) a largely urban set of processes has received less attention than it arguably deserves". To date, planning theory conceded even less attention to the problem (Kaza and Curtis, 2014). As Kaza and Curtis (2014: 364) observe: "While there are strong connections between energy and land use, little work has been done in the land use planning realm". Moreover: "Land use conflicts with renewable energy and distributed generation are only very briefly alluded to, as they are considered nascent technologies and are treated primarily as engineering and technological problems rather than social ones" (ibid., 355).

Considering the effects on the territory and the landscape of favouring the aforementioned polycentric distributed energy scenario, one can imagine the following. First, the territorial levels and the scale at which certain services are produced and provided will radically change (as well as the ownership and control of them). Second, the great structures and infrastructures to which we are accustomed will be replaced by smaller and more dispersed modular units - with lower impacts on the landscape. In this sense, a sort of "inverted territorialisation" will arise: whilst in the twentieth century everything was centralised, in this case the direction is the other way round. Third, the materials and shapes of buildings will radically change: for example, photovoltaic panels are at present generally and simply laid on roofs; instead, they will become increasingly integrated construction elements (roof components and wall panels). Fourth, cities will no longer be isolated from their regional contexts - as has happened as a result of a certain kind of globalisation - but will once again be connected to them and to local resources (Droege, 2002). Fifth, small places (e.g. small villages) and remote places (e.g. rural or mountainous areas) may become more independent and have a new role and importance. ${ }^{17}$ Sixth, and finally, the technological development of electric cars, and the ability to recharge them within their local energy community, will revolutionise the flow and geography of transport. More 
than a future without private cars (as many envisage and recommend), there will be a future of completely different cars (and charging systems).

\section{Conclusions: a framework for (multiple local) utopias}

In conclusion: it is possible to question the present framework of public control over the energy grids and infrastructure, which is still configured on a centralised model of production and distribution.

It goes without saying that a distributed energy system must likewise operate according to a set of safety and security common public standards. The role of the public authorities will be prevalently to establish standard requirements and universal protocols. In this case, the principal "infrastructure" that the public party can offer is the guarantee of universal legal safety and security standards, stable and impartial, that will guarantee equal access to new options. Considered in this way, the law could constitute the framework for the multiple (local) utopias of which Nozick (1974) spoke: that is, a general and abstract institutional framework within which the most varied of local utopian arrangements can flourish. Nozick observed that dreaming of utopia is a positive element in the human spirit. Nevertheless, the mistake made by so many utopians is to imagine a utopia that is the same substantive for the entire society - something impossible in a plural and complex world. Conversely, what can really be done is imagine a general and neutral institutional framework that would allow for numerous local utopias. As Nozick (1974: 311-312) observed: there will not be only one kind of community and only one kind of good life there; "utopia will consist of utopias, of many different and divergent communities in which people lead different kinds of lives under different [private] institutions". In brief: "Utopia is a framework for utopias, a place where people are at liberty to join together voluntarily to pursue and attempt to realise their own vision of the good life in the ideal community but where no one can impose his own utopian vision upon others". Nozick noted that the framework for utopias has two fundamental advantages over every other kind of unitarian substantive utopia. In the first place, it will be acceptable to almost every utopian vision. In the second place, it will be compatible with the realisation of almost all specific utopian projects, though it does not guarantee the universal triumph of any of them (ibid.: $318-319) .{ }^{18}$ It is

\footnotetext{
${ }^{18}$ For a critical discussion of this kind of approach, see for instance Rosen (2005) and Chappell (2008).
} 
possible that "land use planners have a strong role to play in the emerging distributed energy production phase" (Kaza and Curtis, 2014: 365). However, they may have tasks rather different from those of the past. For example, their role might be largely that of furnishing technical support to the community-based enterprises. In other words, they would have to contribute more massively than they have done thus far to new forms of "private planning" (Andersson and Moroni, 2014). A key challenge that arises here is abandonment of the current piecemeal approach to pursue separate utility needs, and instead design integrated energy-management systems. The idea is to design and create coherent energy management systems for an entire community - for instance a new neighbourhood - able to deal simultaneously with many different services, such as electric power, water treatment and supply, waste management, communications, etc. (Lowi and MacCallum, 2014). All of the community's requirements for power can be designed and managed as one integrated on-site system at great saving and satisfaction for users (ibid.: 126). This opens a totally new field of research and work for planners, engineers and architects.Obviously we cannot be sure in advance that all individuals are fully qualified to enter this new word: many important caveats must be considered and taken into account (Hoffman and High-Pippert, 2005). ${ }^{19}$ But nor can we can assume that there is something intrinsically impossible from a cultural and social viewpoint. Moreover, there are also equity problems, such as unequal access and energy poverty issues (Adams and Bell, 2014; Johnson and Hall, 2014). As regards energy poverty, we are convinced that a radical reorganisation of the tasks of the public subject, and more space for experimentation by, and the autonomy of, residential aggregations (or of other kinds) would in many cases ensure more economical access to certain services. ${ }^{20}$ In short, microgrids and smart technologies can be useful for combating "energy poverty" (Oldfield, 2011; Yadoo and Cruickshank, 2012); a problem not only of developing countries but, today, also of many developed countries as well. Moreover, abandoning the traditional model would free enormous amounts of public resources - now used to maintain costly centralised public systems - part of which could also be used to come directly to the aid of the poorest groups unable directly to take advantage of the new options.

\footnotetext{
${ }^{19}$ On the necessity of a more critical understanding on the idea itself of "prosumer", see Ellsworth-Krebs and Reid (2016). Compare also Devine-Wright and Devine-Wright (2009), Comor (2010) and Ritzer et al. (2012).

${ }^{20}$ On energy poverty and local solutions, see for instance Halff and Sovacool (2014).
} 


\section{References}

Adams, C.A., Bell, S. (2014). Local Energy generation Projects: Assessing Equity and Risks. Local Environment. Online first. DOI: 10.1080/13549839.2014.909797.

Affolderbach, J., Schulz, C. (2016). Mobile transitions: Exploring synergies for urban sustainability research. Urban Studies, 53(9): 1942-1957.

Akorede, M.F., Hizam, H., Pouresmaeil, E. (2010). Distributed energy resources and benefits to the environment. Renewable and Sustainable Energy Reviews, 14: 724-734.

Alanne, K., Saari, A. (2006). Distributed energy generation and sustainable development. Renewable and sustainable energy reviews, 10: 539-558.

Alberti, M. (1999). Urban Patterns and Environmental Performance: What Do We Know?. Journal of Planning Education and Research, 19: 151-163.

Alberti, M. (2005). The Effects of Urban Patterns on Ecosystem Function. International Regional Science Review, 28(2): 168-192.

Allison J.A. (2013). The Financial Crisis and the Free Market Cure. Chicago: McGraw Hill.

Anderson, W.P., Kanaroglou, P.S., Miller, E.J. (1996). Urban Form, Energy and the Environment. Urban Studies, 33(1): 7-35.

Andersson, D. E., Moroni, S. (2014). Cities and Private Planning: Property Rights, Entrepreneurship and Transaction Costs. Cheltenham: Edward Elgar.

Asmus, P. (2010). Microgrids, Virtual Power Plants and Our Distributed Energy Future. The Electricity Journal, 23(10): 72-82.

Barton, J., Emmanuel-Yusuf, D., Hall, S., Johnson, V., Longhurst, N., O’Grady, A., Robertson, E., Robinson, E. (2015). Distributing Power: A Transition to a Civic Energy Future. Available at http://www.realisingtransitionpathways.org.uk; accessed 15 September 2015.

Beito, D.T., Gordon, P., Tabarrok, A. (2002). Toward a Rebirth of Civil Society. In D.T. Beito, P. Gordon, A. Tabarrok (eds.), The Voluntary City. Ann Arbor: The University of Michigan Press.

Betsill, M., Stevis, D. (2016). The Politics and Dynamics of Energy Transitions: Lessons from Colorado's (US) 'New Energy Economy'". Environment and Planning C: Government and Policy, 34: 381-396.

Blanch M.J. (2002). Wind Energy Technologies for use in the Built Environment. Wind Engineering, 26(3):125-143.

Bolton, R., Foxon, T.J. (2013). Urban Infrastructure Dynamics. Environment and Planning A, 45(9): 2194-2211.

Boyd, W. (2014). Public Utility and the Low-Carbon Future. UCLA Law Review, 61: 1615-1710.

Bridge, G., Bouzarovskib, S., Bradshawc, M., Eyred, N. (2013). Geographies of Energy 
Transition: Space, Place and the Low-Carbon Economy. Energy Policy, 53: 331-340.

Bronin, S.C. (2008). The Quiet Revolution Revived: Sustainable Design, Land Use Regulation, and the States. Minnesota Law Review, 93: 231-273.

Bronin, S.C. (2010). Curbing Energy Sprawl with Microgrids. Connecticut Law Review, 43(2): 547-584.

Bruch, M., Munch, V., Aichinger, M., Kuhn, M., Weymann, M. and Schmid, G. (2011). Power Blackout Risks. Munich: CRO Forum. Available at https://www.allianz.com/v 1339677769000/media/responsibility/documents/position paper power blackout risks.pdf; accessed 15 September 2015

Brunetta, G. e Moroni S. (2011). Contractual Communities in the Self-Organising City. Dordrecht: Springer.

Bulkeley, H., Broto, V., Maassen, A. (2014). Low-carbon Transitions and the Reconfiguration of Urban Infrastructure. Urban Studies, 51(7): 1471-1486.

Bulkeley, H., McGuirk, P.M., Dowling. R. (2016). Making a smart city for the smart grid? The urban material politics of actualising smart electricity networks. Environment and Planning A. DOI: $10.1177 / 0308518 X 16648152$

Butera, F. (2007) Dalla caverna alla casa ecologica: storia del comfort e dell'energia. Milano: Ambiente edizioni.

Calvert, K. (2016). From 'energy geography' to 'energy geographies': Perspectives on a fertile academic borderland. Progress in Human Geography, 40(1): 105-125.

Cato, N.S., Arthur, L., Keenoy, T., Smith, R. (2008). Entrepreneurial energy Associative entrepreneurship in the renewable energy sector in Wales. International Journal of Entrepreneurial Behaviour \& Research, 14: 5: 313-329.

Calvert K. (2015). From 'Energy Geography' to 'Energy Geographies': Perspectives on a Fertile Academic Borderland. Progress in Human Geography. (Online first: DOI 10.1177/0309132514566343).

Cayford, T., Scholten, D. (2014). Viability of Self-Governance in Community Energy Systems Structuring an Approach for Assessment. TU Delft Working Paper. Available at http://repository.tudelft.nl; accessed 15 September 2015.

Chappell, T. (2008). Utopias and the Art of the Possible. Analyse \& Kritik, 30: 179-203.

Chicco G, Mancarella P. (2009). Distributed multi-generation: a comprehensive view. Renewable and Sustainable Energy Reviews 13:535-51.

Coles, A.M., Piterou, A., Genus, A. (2015). Sustainable Energy Projects and the Community: Mapping Single-Building Use of Microgeneration Technologies in London. Urban Studies. (Online first: DOI 10.1177/0042098015581575).

Comor, E. (2010). Contextualizing and Critiquing the Fantastic Prosumer: Power, Alienation and Hegemony. Critical Sociology, 37(3) 309-327. 
Crousillat, E., Hamilton, R., Antmann, P. (2010). Addressing the Electricity Access Gap. Washington (DC): World Bank. Available at: http://siteresources.worldbank.org; accessed 15 September 2015.

Delaney, C.J., Timmons, D. (1992). High Voltage Power Lines: Do They Affect Residential Property Value. The Journal of Real Estate Research, 7(3): 315-325.

Delucchi, M.A., Jacobson, M.Z. (2011). Providing all global energy with wind, water, and solar power, Part II: Reliability, system and transmission costs, and policies. Energy Policy, 39:1170-1190.

Delucchi, M.A., Jacobson, M.Z. (2013). Meeting the world's energy needs entirely with wind, water, and solar power. Bulletin of the Atomic Scientists, 69(4): 30-40.

Devine-Wright, P., Devine-Wrigth, H. (2009). Public Engagement with Community-Based Energy Service Provision: An Exploratory Case Study. Energy \& Environment, 20(3): 303317.

Dobbs, R., Pohl, H., Lin, D.-Y., Mischke, J., Garemo, N., Hexter, J., Matzinger, S., Palter, R., Nanavatty, R. (2013). Infrastructure Productivity: How to Save \$1 Trillion a Year. McKinsey Global Institute.

Dodson, J. (2014). Suburbia under an Energy Transition: A Socio-technical Perspective, Urban Studies, 51(7): 1487-1505.

Draper, G. Vincent, T., Kroll, M.E., Swanson, J. (2005). Childhood Cancer in Relation to Distance form High Voltage Power Lines in England and Wales: A Case Control Study. British Medical Journal, 330(4): 1290-1294.

Droege, P. (2002). Renewable Energy and the City: Urban Life in an Age of Fossil Fuel Depletion and Climate Change. Bulletin of Science, Technology \& Society, 22(2): 87-99.

Droege, P. (2006). The Renewable City: Dawn of an Urban Revolution. Bulletin of Science, Technology \& Society, 26(2): 141-150.

Dunn, S. (2002). Micropower: New Variable in the Energy-Environment-Security Equation. Bulletin of Science, Technology \& Society, 22(2): 72-86.

Ellsworth-Krebs K., Reid L. (2016). Conceptualising energy prosumption: Exploring energy production, consumption and microgeneration in Scotland, UK. Environment and Planning A. DOI: $10.1177 / 0308518 X 16649182$.

Energy and Strategy Group (2014). Smart Grid Report. Milano: Politecnico di Milano. Available at http://www.energystrategy.it/report/smart-grid.html; accessed 15 September.

EEA (European Environmental Agency) (2012). End-user GHG emissions from energy, Reallocation of emissions from energy industries to end users 2005-2010. EEA Technical report No 18/2012. Available at http://www.eea.europa.eu; accessed 31 August 2015.

Farrell, J. (2011). Democratizing the Electricity System. Available at www.ilsr.org; accessed 15 September 2015. 
Farrell, J. (2012). Rooftop Revolution. Institute for Local Self-Reliance. Available at www.ilsr.org; accessed 15 September 2015.

Farrell, J. (2014). Beyon Utility 2.0 to Energy Democracy. Institute for Local Self-Reliance. Available at www.ilsr.org; accessed 15 September 2015.

Foldvary, F. E. (2005). Infrastructure: optimal private and governmental funding and provision. Economic Affairs, 25(1), 25-30.

Friedrichsen, N., Brandstätt, C., Brunekreeft, G. (2014). The Need for More Flexibility in the Regulation of Smart Grids - Stakeholder involvement. International Economics and Economic Policy, 11: 261-275.

Geddes, R. R. (1992). "Historical Perspective on Electric Utility Regulation”. A. Regulation, 15, 75.

Geels F.W. (2002). Technological Transitions as Evolutionary Reconfiguration Processes: A Multi-Level Perspective and a Case-Study. Research Policy, $\quad 31(8-9)$ : 1257-74.

Geels, F.W. (2014). Regime Resistance against Low-Carbon Transitions. Theory, Culture \& Society, 31(5): 21-40.

Geels, F.W., Kemp, R. (2007). Dynamics in Socio-Technical Systems: Typology of Change Processes and Contrasting Case Studies. Technology in Society, 29: 441-455.

Glass, A., Levermore, G. (2011). Micro wind turbine performance under real weather conditions in urban environment. Building Serv. Eng. Res. Technol., 32(3): pp. 245-262.

Goldthau, A. (2014). Rethinking the governance of energy infrastructure: scale, decentralization and polycentrism. Energy Research \& Social Science, 1: 134-140.

Goulden, M., Bedwell, B., Rennick-Egglestone, S., Rodden, T., Spence, A. (2014). Smart grids, smart users? The role of the user in demand side management. Energy Research \& Social Science, 2: 21-29.

Gul, M., Kotak, Y., Muneer, T. (2016). Review on recent trend of solar photovoltaic technology. Energy Exploration \& Exploitation, 34(4): 485-526.

Hayek, F.A. (1976). The Denazionalisation of Money: An Analysis of the Theory and Practice of Concurrent Currencies. London: Istitute of Economic Affairs.

Hayek, F.A. (1960). The Constitution of Liberty. Chicago: The University of Chicago Press.

Hodson, M., Marvin, S. (2010). Can Cities Shape Socio-Technical Transitions and How Would We Know if they Were?. Research Policy, 39: 477-485.

Hoffman, S.M., High-Pippert, A. (2005). Community Energy: A Social Architecture for an Alternative Energy Future. Bulletin of Science, Technology and Society, 25(5): 387-401.

Houck, J., Rickerson, W. (2009). The Sustainable Energy Utility (SEU) Model for Energy Service Delivery. Bulletin of Science, Technology and Society, 29(2): 95-107.

Jensen, M.G., Johnson, B., Lorenz, E., Lundvall, B.A. (2007). Forms of Knowledge and Modes 
of Innovation. Research Policy, 36: 680-693.

Johnson, V.C.A., Hall, S. (2014). Community Energy and Equity: The Distributional Implications of a Transition to a Decentralised Electricity System. People, Place and Policy: 8(3): 149-167.

Halff, A., Sovacool, B. K., \& Rozhon, J. (Eds.). (2014). Energy poverty: global challenges and local solutions. Oxford University Press: Oxford.

Hoornweg, D., Sugar, L., Gómez, C.L. (2011). Cities and greenhouse gas emissions: moving forward. Environment \& Urbanization, 23(1): 207-227.

Houck, J., Rickerson, W. (2009). The Sustainable Energy Utility (SEU) Model for Energy Service Delivery" Bulletin of Science, Technology and Society, $\quad$ 29(2): 95-107.

IEA (International Energy Agency) (2014). Keyworld Energy Statistics 2014. Paris: OECD. Available at http://www.iea.org; accessed 15 September 2015.

Kaza, N., Curtis, P. (2014). The Land Use Energy Connection. Journal of Planning Literature, 29(4): 355-369.

Kiesling, L. (2010). The Knowledge Problem, Learning, and Regulation: How Regulation Affects Technological Change in the Electric Power Industry. Studies in Emergent Order, 3: 149-171.

Kiesling (2012). Regulation's Effect on Experimentation in Retail Electricity Markets. In The Annual Proceedings of the Wealth and Well-Being of Nations, 4: 89-113.

Knight, E. (2012). The Economic Geography of Financing Clean Energy Technologies. Competition and Change, 16(2): 77-90.

Lawhon, M., Murphy, J.T. (2011). Socio-technical regimes and sustainability transitions. Progress in Human Geography, 36(3): 354-378.

Lewis, T. G. (2014). Critical infrastructure protection in homeland security: defending a networked nation. John Wiley \& Sons: Hoboken, NJ.

Li, C.-Y., Lee, W.-C., Lin, R.S. (1998). Risk of Leukemia in Children Living Near High-Voltage Transmission Lines. Journal of Occupational and Environmental Medicine, 40(2): 144-147.

Lovins, A.B. (2011). Renewable Energy's 'Footprint' Myth. The Electricity Journal, 24(6): 1-8.

Lowi, A., MacCallum, S. (2014). Community technology: liberating community development. In S. Moroni, and D. Andersson (eds.), Cities and Private Planning, Edward Elgar Publishing, Cathelham, pp106-134.

MacCallum, S.H. (1970). The art of community. Menlo Park, CA: Institute for Humane Studies.

Mazza, P. (2002). Climate Change Solutions as Economic Development: Transforming Barriers Into Drivers. Bulletin of Science, Technology \& Society, 22(2): 158-167.

McGuirk, P., Dowling, R., Bulkeley, H. (2014). Repositioning urban governments? Energy efficiency and Australia's changing climate and energy governance regimes. Urban Studies, 51(13): 2717-2734. 
McLean, A., Bulkeley, H., Crang, M. (2015). Negotiating the urban smart grid: Socio-technical experimentation in the city of Austin. Urban Studies. DOI: 10.1177/0042098015612984.

Mendes, G., Ioakimidis, C. Ferrão, P. (2011). On the Planning and Analysis of Integrated Community Energy Systems. Renewable and Sustainable Energy Reviews, 15: 4836-4854.

Menna, P., Pauli, F. (2010). L'energia solare. Bologna, Il Mulino.

Mertens, S., van Kuik, G., van Bussel, G. (2003). Performance of an H-Darrieus in the Skewed Flow on a Roof. Journal of Solar Energy Engineering, 125: 433-440.

Moroni, S. (2014). Towards a General Theory of Contractual Communities. In D. Andersson and S. Moroni (eds.), Cities and Private Planning. Cheltenham, Edward Elgar: 38-65.

Muller, R. (2012). Energy for Future Presidents. New York: Norton.

Newcomb, J., Lacy, V., Hansen, L., Bell, M. (2013). Distributed energy resources: Policy implications of decentralization. The Electricity Journal, 26(8): 65-87.

Nozick, R. (1974). Anarchy, state, and utopia (Vol. 5038). Basic books.

Oldfield, E. (2011). Addressing energy poverty through smarter technology. Bulletin of Science, Technology \& Society, 31(2), 113-122.

Oliver J.G.J., Janssens-Maenhout G., Muntean M., Peters J. (2013). Trends in Global CO2 Emissions, PBL Netherlands Environmental Assessment Agency, The Hague.

Olsen, J.H., Nielsen, A., Schulgen, G. (1993). Residence Near High Voltage Facilities and Risk of Cancer in Children. British Medical Journal, 307(9): 891-895.

Outka, U. (2012). Environmental Law and Fossil Fuels: Barriers to Renewable Energy. Vanderbilt Law Review, 65(6): 1679-1721.

Outka, U. (2011). The Renewable Energy Footprint. Stanford Environmental Law Journal, 30: 241-309.

Pender, J.L., Weber, J.G., Brown, J.P. (2014). Sustainable Rural Development and Wealth Creation: Five Observations Based on Emerging Energy Opportunities. Economic Development Quarterly, 28(1): 73-86.

Pitt, D. (2008). Taking the Red Tape Out of Green Power. Available at http://www.gracelinks.org; accessed 15 September 2015.

Rule, T.A. (2010). Renewable Energy and the Neighbors. Utah Law Review, 4: 1223-1276.

Raven, B., Schot, J., Berkhout, F. (2012). Space and Scale in Socio-Technical Transitions. Environmental Innovation and Societal Transitions, 4: 63-78.

Rehman, S., Baseer, M.A., Meyer, J.P., Alam, M.M., Alhems, L.M., Lashin, A., Al Arifi, N. (2016). Suitability of utilizing small horizontal axis wind turbines for off grid loads in eastern region of Saudi Arabia. Energy Exploration \& Exploitation, 34(3): 449-467.

Rezaie, B., \& Rosen, M. A. (2012). District heating and cooling: Review of technology and 
potential enhancements. Applied Energy, 93, 2-10.

Ribeiro, P.F., Polinder, H., Verkek, M.J. (2012). Planning and designing smart grids: philosophical considerations. IEEE Technology and society magazine, fall: 34-43.

Ritzer, G., Dean, P., Jurgenson, N. (2012). The Coming of Age of the Prosumer. American Behavioral Scientist, 56(4) 379-398.

Rosen, M.D. (2005). The Surprisingly Strong Case for Tailoring Constitutional Principles. University of Pennsylvania Law Review, 153: 1513-1637.

Rutherford, J., Coutard, O. (2014). Urban Energy Transitions: Places, Processes and Politics of Socio-technical Change. Urban Studies, 51(7) 1353-1377.

Rydin, Y., Turcu, C., Guy, S., Austin, P. (2013). Mapping the coevolution of urban energy systems: pathways of change. Environment and Planning A, 45: 634-649.

Salkin, P.E. (2012). The Key to Unlocking the Power of Small Scale Renewable Energy: Local Land Use Regulation. Journal of Land Use, 27(2): 339-367.

Scheer, H. (2002). The Solar Economy Renewable Energy for a Sustainable Global Future. London: Earthscan.

Scheer, H. (2010). Der energethische Imperativ: 100 Prozent jetzt: wie der vollständige Wechsel zu erneuerbaren Energien zu realisieren ist. Kunstmann.

Sermage-Faure, C., Demoury, C., Rudant, J., Goujon-Bellec, S., Guyot-Goubin, A., Deschamps, F., Hemon, D., Clavel, J. (2013). Childhood Leukemia Close to High-Voltage Power Lines The Geocap Study, 2002-2007. British Journal of Cancer, 108(9): 1899-1906.

Seyfang, G., Hielscher, S., Hargreaves, T., Martiskainen, M., \& Smith, A. (2014). A Grassroots Sustainable Energy Niche? Reflections on Community Energy in the UK. Environmental Innovation and Societal Transitions, 13, 21-44.

Sims, S., Dent, P. (2005). High-Voltage Overhead Power Lines and Property Values: A Residential Study in the UK. Urban Studies, 42(4): 665-694.

Skjølsvold, T.M., Ryghaug, M. (2015). Embedding Smart Energy Technology in Built Environments: A Comparative Study of Four Smart Grids Demonstration Projects. Indor and Built Environment. (Online first: DOI 10.1177/1420326X15596210).

Sohrabi, M.-R., Tarjoman, T., Abadi, A., Yavari, P. (2010). Living Near Overhead High Voltage Transmission Power Lines as a Risk Factor for Childhood Acute Lymphoblastic Leukemia: a Case-control Study" Asian Pacific Journal of Cancer Prevention, 11: 423-427.

Sovacool, B. K. (2014). What are we doing here? Analyzing fifteen years of energy scholarship and proposing a social science research agenda. Energy Research \& Social Science, 1, 1-29.

Tame, C.R. (1998).Cooperation without community. Philosophical Notes, 11, 1-4.

Toledo, O.M., Filho, D.O., Diniz, A.S.A.C. (2010). Distributed Photovoltaic Generation and Energy Storage Systems: A Review. Renewable and Sustainable Energy Reviews, 14: 506-511. 
Tricarico, L. (2015). Energia come community asset e orizzonte di sviluppo per le imprese di comunità. Impresa Sociale. Impresa Sociale, 5.2015, pp. 53-64.

UBS (2014). Will solar, batteries and electric cars re-shape the electricity system? Q-Series.

U.S. Department of Energy (2004). How Much Land Will PV Need to Supply Our Electricity?. Available at http://www.nrel.gov; accessed 7 September 2015.

U.S. Department of Energy (2013). U.S. Energy Sector Vulnerabilities to Climate Change and Extreme Weather. Available at http://www.energy.gov; accessed 7 Semptember 2015.

U.S. Department Of Energy. (2014). Smart Grid System Report. (available at www.smartgrid.gov).

Yadoo, A., Cruickshank, H. (2012). The role for low carbon electrification technologies in poverty reduction and climate change strategies: A focus on renewable energy mini-grids with case studies in Nepal, Peru and Kenya. Energy Policy, 42, 591-602.

Waraich, R.A., Galus, M.D., Dobler, D., Balmer, M., Andersson, G., Axhausen, K.W. (2010). Plug-in hybrid electric vehicles and smart grids. Transportation Research, 28: 74-86.

Warren, G.S. (2014). Vanishing Power Lines and Emerging Distributed Generation. Wake Forest Journal of Law \& Policy, 4(2): 347-396.

Wiseman, H., Grisamer, L., Saunders, E.N. (2011). Formulating a Law of Sustainable Energy: The Renewables Component. Pace Environmental Law Review, 28(3): 827-906.

Zakariazadeh, A., Jadid, S., Siano, S. (2014). Multi-objective scheduling of electric vehicles in smart distribution system. Energy Conversion and Management, 79: 43-53. 